\title{
BEEF PRODUCTION ON THE GRASSLANDS OF THE CANTERBURY FOOTHILLS
}

\section{J. O. Acland}

\author{
Mt Peel Station, Canterbury
}

BeEF production in the foothills of Canterbury will have an increasing role to play in the meat production from that area. It is important that the mistakes and successes that some of us have made are discussed so that those starting out will be able to benefit from them. This paper covers the progress and problems of one area only, that of Mt Peel Station, which is situated on the south banks of the Rangitata River and covers an area of 7300 ha.

The topography of Mt Peel is such that it can easily be divided into three areas. First, an area of 800 ha of ploughable flats situated on three terrace layers rising from 300 to $600 \mathrm{~m}$. The soils in this area are comprised of Kakahu, Hororata, Mayfield and Waimakariri types. To date, 650 ha have been ploughed and sown in permanent pasture. The second area is made up of 2400 ha of tussock country rising from approximately 460 to $1100 \mathrm{~m}$ and most of this country lies in a north-easterly direction. The soils here are mainly Kakahu and Hurunui. This area is steep, often rising $600 \mathrm{~m}$ in one mile of track. The vegetation is silver and fescue tussock and remnants of snow grass. In addition to the 2400 ha in this area there are 800 ha of bush and scrub that cannot be grazed. The third area comprises 3200 ha of country between 900 and $1700 \mathrm{~m}$. Kaikoura and some Hurunui steepland soils are found here. The only grazing that this area has is by cows in the autumn after weaning, otherwise it is not stocked owing to its very low stock carrying capacity and the need for this class of country to be spelled from grazing animals.

The climate on Mt Peel varies from the wettest end near Peel Forest where the rainfall is $1320 \mathrm{~mm}$ per year to the drier western end where the annual rainfall is only $760 \mathrm{~mm}$. The wettest months are October, November and December and in the winter there are hard frosts and snow lies for up to two months on the country above $\mathbf{1 1 0 0} \mathrm{m}$. North-west winds are strong and frequent in the spring months.

Stock numbers have steadily increased over the years with the greatest increases coming in the last 10 years: 


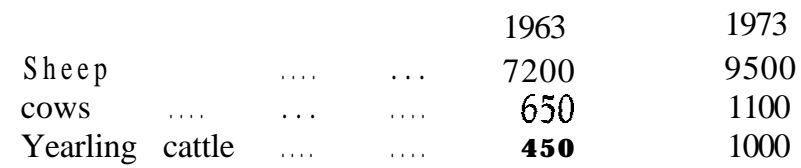

The sheep have been Romney from a halfbred background but a change to Coopworths is being made.

Angus cows form the base of the breeding herd and we have used these cows in an artificial insemination programme, inseminating 600 cows a year with Charolais, Simmental, Limousin and Angus semen. We cannot see a large number of beef farmers using A.I. for two reasons. First, it causes management problems in that the cows have a calf at foot and a large amount of feed is required adjacent to well-equipped stockyards. Secondly, there will not be the need for everybody to use A.I. if a two-tier system is devised whereby those farmers who have performance-recorded rheir cows then use semen from the best progeny-tested bulls on their ,top cows. In this way the farmer purchasing run bulls will be buying bulls just one generation away from a progeny-tested sire and there would be a large number of top bulls available for sale at reasonable, prices.

Because Mt Peel has two distinct types of country we are able to carry out both a beef breeding and a beef fattening programme. The breeding is all done on the tussock country and the young stock (under 18 months) never go on to this area. Conversely, the cows do go on to the flats for 6 weeks at mating time and the first calving heifers, calving as 2-year-olds, do calve on the flats. Beef cows do, and will, continue to assist in the development and control of the tussock country.

When developing this area we have tried always to follow a set pattern of putting in access tracks first because these are necessary to get the fencing material out and to facilitate stock movements, The next thing is the subdivision of the hill blocks. To date we have subdivided them into 120 ha blocks. We thought that with large mobs of 500 cows we could control the tussock on areas of this size, but we have been wrong. Without a doubt silver and fescue tussock has got out of control and in places silver tussock covers $50 \%$ of the ground with a canopy shading $75 \%$ of the ground. The problem is more serious where rainfall is higher and it also appears that silver tussock responds to topdressing and it is on blocks that have had 1.25 to 1.88 tonnes of super-phosphate that the tussock is thickest. One method of controlling this problem is by cultivation and we would say that we would cultivate all tussock country where possible. As well as 
getting rid of the tussock better grasses can be introduced more rapidly. The second method open to us would be to burn.

Looking back, we should have burnt the lower tussock country before we started our development plan because it is now going to be difficult to get an adequate burn owing to the green clover growth. Another method would be to feed out hay to large mobs of cows and use the tussock as the roughage part of the diet but we have few hill blocks suitable for feeding out hay. The last method open to us is the use of large mobs of cows in a rotational grazing system. As yet we have not proved that this method will work other than on some very small flat areas where we have achieved a grazing pressure of 25 cattle beasts per hectare for 2 months (with a hay supplement) and under this intensity the tussock has been eaten. Of course, to do this on a large scale means reducing the size of our hill blocks to 60 ha, which we intend to do. The problem of making this system work is to get a large enough stock number per hectare because in most cases the country is in large broken areas running from 460 to $1100 \mathrm{~m}$ on one tussock face which makes fencing and stock handling very difficult.

Following increased stock numbers we aerially oversow white and red clover along with cocksfoot, dogstail and ryegrass. This seed has been sown before the superphosphate is spread, and at the end of winter when the cows have opened up the tight sward. To date, after 4 or 5 years, there is no sign of ryegrass, little cocksfoot and dogstail, but a strong, vigorous clover stand enough to kill cows with bloat.

Initial applications of $250 \mathrm{~kg} / \mathrm{ha}$ of sulphur 400 superphosphate are made, followed by $190 \mathrm{~kg}$ every second year.

Having increased the production of this tussock grassland area, the logical move is to find the most suitable cow for this country. This cow must be of medium size, because a large one requires more feed, and must wean a calf at 6 months old which is no less than $227 \mathrm{~kg}$. To achieve this we might need a crossbred cow - i.e., a Friesian $\mathbf{x}$ Hereford or Simmental $\times$ Angus, A terminal sire would then be used on this cow and the offspring slaughtered.

If farmers would accept a stratification system we would see in the higher country the use of a milk breed type bull being used on a percentage of straightbred cows. This first cross cow would then be sold to a farmer on the easier tussock country where he would mate her to a terminal sire. The resulting calf would then be fattened on the fattening country of the Canter- 
bury Plains. For this system to be successful it is vital to have good lines of straightbred cows and this is where well-recorded stud cattle or group breeding schemes will play such an important part in improving the performance of our straightbred herds. Without a doubt the most important requirement of any breeding cow is the ability to produce a live calf regularly every 12 months of her life. There is no point in breeding a cow with high milk production which means a heavy calf unless she can fill this requirement.

The calf produced on our higher tussock country is then shifted down on to the flats, This area has been developed by cultivation from the same type of sward as the tussock country. It has been ploughed and sown in root crops for two winters before being sown down in permanent pasture. Once in grass it is our aim to leave it this way. Approximately 1400 tonnes of silage are cut off this area annually as well as some hay.

On this country young cattle are rotationally grazed, usually in front of sheep, and very seldom with them. All the fattening cattle and surplus breeding stock are sold at 18 months of age and by getting rid of them before the second winter we are making the best use of the grass at the height of its production. It would not be economical for us to winter them twice. Our aim has always been to get our steers to a carcass weight of $270 \mathrm{~kg}$ by 18 months. We have never achieved this and our killing weights have been round 227 to $236 \mathrm{~kg}$. We have come close to achieving our aim by breeding Charolais $X$ Angus steers which gave us our additional $32 \mathrm{~kg}$ of beef at 18 months. We believe that some of the European breeds will play a major part in the future of our beef production but as yet we do not know which breed will fit into our particular system.

Sheep still play a major part in the grassland foothills of Canterbury and will continue to do so because they help to achieve good pasture utilization by eating some vegetation that the cattle do not eat and in our case they help to control young broom and gorse.

The South Island foothills country is understocked with cattle. Most areas carry 1 cattle beast to every 20 sheep compared with the North Island which has a 1:5 ratio on similar country and we at Mt Peel have, a 1:4 ratio.

Without a doubt cattle will play an increasingly important role on the tussock grassland foothills of Canterbury, not only in the production of beef but also in the improvement and utilization of the grassland itself. 